\title{
The Application of Access Management in Commercial Area
}

\author{
Siqi Gao, Xiaokuan Yang \\ Transportation College of Metropolitan, Beijing University of Technology, Beijing, China \\ Email: 823231976@qq.com, xiaokuan@bjut.edu.cn
}

How to cite this paper: Gao, S.Q. and Yang, X.K. (2016) The Application of Access Management in Commercial Area. World Journal of Engineering and Technology, 4, 5159.

http://dx.doi.org/10.4236/wjet.2016.43C007

Received: May 12, 2016

Accepted: September 19, 2016

Published: September 22, 2016

\begin{abstract}
With the rapid development of automobile ownership and roadway network in China, there is more and more travel demand in the city of Beijing, China. Large commercial areas attract high volumes of traffic, which greatly impacts traffic movement on roadways, producing congestion and safety problems. What is more serious is that existing design of the parking lot, the location of access, layout of driveway, and passage of circulation are not desirable, causing potential conflicts and traffic delays. This paper mainly investigates the impact of the existing design of parking lot and layout of access and driveways at commercial areas around intersection in Beijing. The overall goal of this study is to use access management technologies to find out the measures for commercial area to improve roadway safety and operational efficiency. Some measures of improvements are proposed based on the analysis, including addition of right turn lanes, increase of driveway throat length and incorporation of traffic signs to guide on-site circulation. To accomplish the study objective, a total of 10 commercial areas around intersection were selected and some necessary data were collected at access points including traffic volume of each access and the frontage roadways during peak hours, access type, location, and spacing. The field investigations were conducted for 2 weekends for each area. Meanwhile, the peak hours were 10:00 to 12:00 a.m. on weekends. The data from field investigations show that the number and location of the access is different from place to place. Access driveway is closely located at the signalized intersection mostly. Other problems are also observed based on field investigation such as shortage of the access spacing. The result of this study can be a reference for traffic management on other similar areas in Beijing.
\end{abstract}

\section{Keywords}

Access Management, Commercial, Parking 


\section{Introduction}

With the rapid development of the roadway network and skyrocketing increase of car ownership in China, there are more and more travel demands in the city of Beijing, China. Numerous major shop-ping centers have been developed around intersections, producing serious congestion and safety problems. Therefore, the objective of this study is to figure out problems through field observation and use access management techniques to find improvement approach for commercial area.

Access management has been defined as "the systematic control of the location, spacing, design, and operation of driveways, median openings, interchanges, and street connections to a roadway", as well as the application of median treatments, auxiliary lanes, and the appropriate spacing of traffic signals [1]. Access management techniques have been defined and applied in the US for many years. Previous literature shows that well managed urban arterial roadways have been shown to be around $40 \%$ to $50 \%$ safer than poorly managed urban arterials on a per-vehicle-mile basis [2].

In this paper four commercial areas in Wanging area have been chosen to conduct detailed data collection and analysis. Moreover, these four commercial areas are in the corner of the same intersection respectively. The locations are shown in Figure 1.

In addition, to achieve this objective, it is important to conduct the data collection from field investigations. In this paper, the field investigations were conducted for 2 weekends for each area. Meanwhile, the peak hour was 10:00 to 12:00 a.m. on weekends. Through the investigation, it was found that at the weekend, the commercial areas will attract a lot of customers to eat, go shopping or enjoy for fun. In addition, the four commercial areas are at the four corners of the same intersection, at the weekend, it will make the intersection more confused. It is proved that the selection of these four business areas for conducting research is very appropriate.

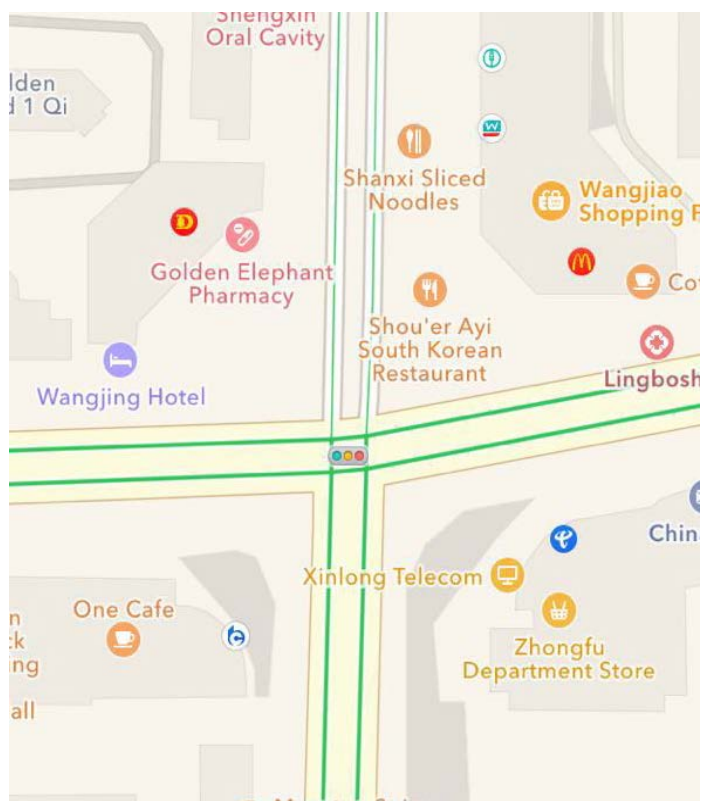

Figure 1. The location of commercial areas. 


\section{Literature Review}

The proper management of access on urban roadways has been an issue in planning, design and management for decades. Review of the literature reveals that a number of research projects have been conducted to analyze the safety and operational impacts of access management techniques. The TRB Access Management Manual sets forth some principles of access management. It is well known that crash rates and delay increase as access density increases.

The Minnesota Department of Transportation commissioned a statewide study of the safety effects of access management. The results indicated that roadway segments with the highest access density have crash rates higher than average, regardless of type of access, speed limit, or volume of traffic. The study revealed a direct and statistically significant correlation between crash rates and access density for all state highway categories [2].

A study conducted by Eisele, and Frawley discussed the effect of unlimited access of arterial streets on traffic operation and safety. The result showed that unlimited access onto arterial streets had a negative effect, which caused the capacity to decline and average speeds to decrease [3].

Gluck, et al. presented results of specially conducted operations analyses at 22 sites to study the effect of access spacing on traffic operations. Information was gathered on the number and percentage of through vehicles impacted by right turns. Access separation distances for various operating speeds and right-turn volumes were based on the likelihood of minimizing spillback across an upstream driveway over a series of driveways along a 1/4-mile section of road [4].

Another study by Gluck discussed issues encountered in a retrofit development project for a roadway in a densely developed area [5]. This study reviewed operational and safety problems and identified a theoretical access configuration along the NY27 corridor that could mitigate these problems. In addition this study reviewed the approved alternative and presented a series of conclusions that could be applied to help avoid similar conditions.

Traffic volumes and congestion continue to increase on arterial roads. As such the safety and performance of these roads is a continued concern. Transportation systems must be evaluated on an ongoing basis to ensure that people and goods can be moved as efficiently and safely as possible. A study of Gluck, et al. developed the prioritization process based on principles of performance indices that can be utilized to target arterial roads that would benefit from access management techniques and principles [6].

Several studies have also documented the business impacts of higher levels of access management and have found little or no impact on business sales, business turnover, new business development, or customer satisfaction. Business persons often express great concern about access management, but the actual impacts appear rather benign. This means that stakeholder education is a very important component of a comprehensive access management program [7].

In summary these analyses are mostly focused on the safety and operational impact 
of access design on surrounding traffic. Some methodologies and theories in the literature review can be, to some extent, applied for analysis of access management in the Wangjing Neighborhood commercial area.

\section{Data Collection and Analysis}

To make an adequate investigation on the access management problems at the selected commercial places the research emphasis focuses mainly on several aspects such as the location, the commercial scale in terms of service floor area, parking layout, the opening of access, and conflicts.

\subsection{General Information of the Commercial Areas}

The basic information of the commercial areas contains the geographical location, floor area, form of parking lot, locations of the parking lot and the number of entrances and exits, which are shown in Table 1. The detailed situation of entrances and exits is shown in Figure 2.

\subsection{Investigation on the Data of the Access}

Based on field observations it is found that the conflicts in commercial places have three general types: vehicle-to-vehicle conflict, vehicles-to-bicycle conflict and vehicleto-pedestrian conflict. Due to the time limits, in this paper we only discuss the vehicleto-vehicle conflict. The other conflicts will be studied in next step.

Due to the fact that there is no crash data available in this area, we have to con-duct conflict study instead. Video camera is then used to record the occurrence of the conflict. Conflicts number is defined as the counting number when red light is on. Table 2 shows flow and conflicts between vehicles in each access.

\subsection{Intersection and Road Conditions around the Access}

Apart from the study of the situation of the access, we also need to make an investigation about the intersection and road conditions around the access to achieve the goal of

Table 1. The basic information of the business districts.

\begin{tabular}{|c|c|c|c|c|c|c|c|}
\hline $\begin{array}{l}\text { Commercial } \\
\text { Number }\end{array}$ & $\begin{array}{l}\text { Commercial } \\
\text { Name }\end{array}$ & Location & $\begin{array}{c}\text { Covering } \\
\text { Area } \\
\text { (Hectare) }\end{array}$ & $\begin{array}{l}\text { Built-up } \\
\text { Area } \\
\left(10000 \mathrm{~m}^{2}\right)\end{array}$ & $\begin{array}{l}\text { Commercial } \\
\text { Scale }\end{array}$ & $\begin{array}{l}\text { Parking } \\
\text { Mode }\end{array}$ & $\begin{array}{c}\text { The number } \\
\text { of access }\end{array}$ \\
\hline 1 & $\begin{array}{l}\text { Da Zhong } \\
\text { Electronics }\end{array}$ & $\begin{array}{l}\text { Outside } \\
5 \text { th ring }\end{array}$ & 0.35 & 1.10 & small & ground & 1 \\
\hline 2 & $\begin{array}{l}\text { Jin Baiwan } \\
\text { Roast-duck } \\
\text { Restaurant }\end{array}$ & $\begin{array}{l}4 \text { th ring - 5th } \\
\text { ring road }\end{array}$ & 0.42 & 1.21 & small & ground & 2 \\
\hline 3 & $\begin{array}{l}\text { WangJiao } \\
\text { Square }\end{array}$ & $\begin{array}{l}4 \text { th ring - 5th } \\
\text { ring road }\end{array}$ & 0.77 & 1.35 & small & ground & 2 \\
\hline 4 & $\begin{array}{c}\text { The Blessing } \\
\text { Store }\end{array}$ & $\begin{array}{l}4 \text { th ring }-5 \text { th } \\
\text { ring road }\end{array}$ & 0.61 & 0.99 & small & ground & 2 \\
\hline
\end{tabular}



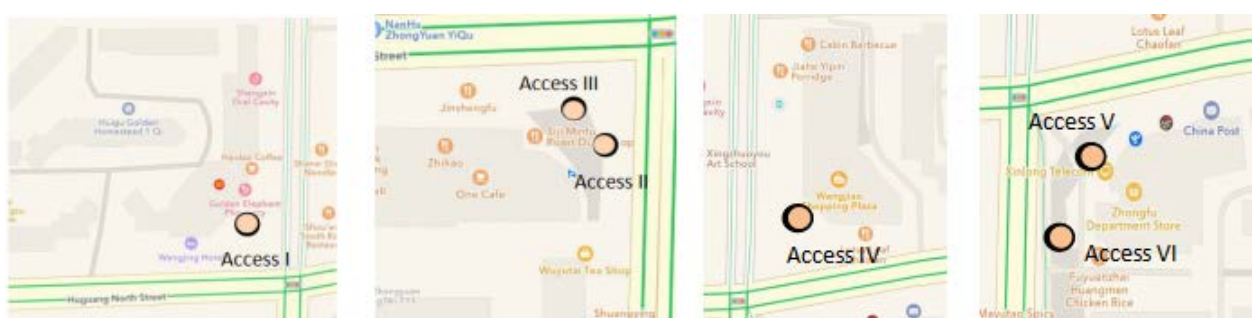

Figure 2. Commercial area $1 \& 2 \& 3 \& 4$.

Table 2. Access situation.

\begin{tabular}{cccccc}
\hline \multirow{2}{*}{$\begin{array}{c}\text { Commercial } \\
\text { Number }\end{array}$} & $\begin{array}{c}\text { Access } \\
\text { Number }\end{array}$ & $\begin{array}{c}\text { Position of } \\
\text { access }\end{array}$ & entrance & exit & $\begin{array}{c}\text { Conflict } \\
\text { point }\end{array}$ \\
\cline { 4 - 5 } 1 & I & Intersection & 437 & 385 & 5 \\
2 & II & Intersection & 310 & 0 & 2 \\
3 & III & Intersection & 0 & 286 & 5 \\
4 & IV & Intersection & 402 & 473 & 5 \\
& V & Intersection & 459 & 0 & 2 \\
\hline
\end{tabular}

the study. As mentioned before, the distance and the control type are the two major elements that influence the traffic operation. The distance refers to the length between access and the nearest signalized intersection. Meanwhile, the related road is also investigated including the road control type and lane number. They are no control, physical median and signalization, respectively. The further information is listed in Table 3.

According to the characteristics of commercial areas, we settled the schedule on weekends, and extended the investigation periods. It can be seen that the accesses are built on the side of the main road and intersection as indicated in the photos. Through the investigation and analysis of the commercial areas, seven entrances and exits have their own problems. Thus, he following exploration is based on the analysis of each business area.

\subsubsection{Da Zhong Electronics}

Da Zhong Electronics is a small shopping mall to buy electrical appliances for people. So at the weekend, especially when shopping malls discount, it will attract a lot of people come here. And through the investigation, $90 \%$ people will come here by car. So the access management of the parking lot is particularly important. As shown in the picture, this commercial area is only one access, access I. And the access is divided into two lanes, one is for coming in the parking lot and the other is for coming out it. Moreover, access $I$ is beside the intersection. If there are many vehicle coming in through the access, the car maybe wait for a long time. It will cause the traffic jam on the intersection and the illegal parking outside the parking lot. 
Table 3. Road situation around the access.

\begin{tabular}{|c|c|c|c|c|c|c|c|}
\hline \multicolumn{3}{|c|}{ Access } & \multicolumn{3}{|c|}{ Road Situation } & \multirow{2}{*}{$\begin{array}{l}\text { The type of } \\
\text { intersection }\end{array}$} & \multirow{2}{*}{$\begin{array}{l}\text { Date and } \\
\text { time period }\end{array}$} \\
\hline Num. & $\begin{array}{l}\text { The } \\
\text { position }\end{array}$ & $\begin{array}{l}\text { Distance from } \\
\text { Intersection }\end{array}$ & $\begin{array}{l}\text { Name } \\
\text { nearby }\end{array}$ & $\begin{array}{l}\text { The grade } \\
\text { of road }\end{array}$ & $\begin{array}{l}\text { The control } \\
\text { type }\end{array}$ & & \\
\hline I & Intersection & 0 & $\begin{array}{c}\text { Nanhu } \\
\text { North Road }\end{array}$ & $\begin{array}{c}\text { The } \\
\text { secondary } \\
\text { road }\end{array}$ & $\begin{array}{l}\text { Physical } \\
\text { Median }\end{array}$ & & \\
\hline II & Intersection & 0 & Huguang & $\begin{array}{l}\text { The main } \\
\text { road }\end{array}$ & $\begin{array}{l}\text { Physical } \\
\text { Median }\end{array}$ & & \\
\hline III & Intersection & 0 & North Street & $\begin{array}{c}\text { The main } \\
\text { road }\end{array}$ & $\begin{array}{l}\text { Physical } \\
\text { Median }\end{array}$ & The grade & $\begin{array}{l}2016.3 . \\
20-21\end{array}$ \\
\hline IV & Intersection & 0 & $\begin{array}{l}\text { Huguang } \\
\text { North Street }\end{array}$ & $\begin{array}{l}\text { The main } \\
\text { road }\end{array}$ & $\begin{array}{l}\text { Physical } \\
\text { Median }\end{array}$ & & $\begin{array}{l}\text { 10:00 a.m - } \\
\text { 12:00 noon }\end{array}$ \\
\hline $\mathrm{V}$ & Intersection & 0 & Nanhu & $\begin{array}{c}\text { The main } \\
\text { road }\end{array}$ & $\begin{array}{l}\text { Physical } \\
\text { Median }\end{array}$ & & \\
\hline VI & Segment & 69 & North Road & $\begin{array}{c}\text { The main } \\
\text { road }\end{array}$ & $\begin{array}{l}\text { Physical } \\
\text { Median }\end{array}$ & & \\
\hline
\end{tabular}

\subsubsection{Jin Baiwan Roast-Duck Restaurant}

Jin Baiwan Roast-duck Restaurant is a restaurant. So as we known there are many people coming here at the weekend, especially when people have lunch at noon. There are two accesses for this restaurant, access II and access III, respectively. The two accesses are side by side, and one is for coming in and the other is for coming out. But they are so close that the vehicle cannot be easily accessible. The real situation is shown in Figure 3.

\subsubsection{Wang Jiao Square}

Wang Jiao Square is a comprehensive market and it has a large traffic flow on weekends. What's more, the plaza is located by the intersection, and has only one access, access IV, that face to the intersection. This kind of access is very special and it can cause a traffic jam as long as one car comes out through it. At the same time, there is a lot of illegal parking in the vicinity of the entrance to avoid parking fee. This phenomenon will cause the congestion of the road. The conflict is shown in Figure 4.

\subsubsection{The Blessing Stores}

The Blessing Stores is also located by an intersection, and it has two accesses, V\&VI, one is on the intersections and the other is on the Arterial Road. But the intersection V\&VI are both one-way drive, the cars go in through V and come out through VI. When the traffic flow arises, all the cars will be stuck in the access $\mathrm{V}$, and eventually affects the operation of the intersection, as shown in Figure 5.

\section{Improvement Approach}

Based on the access management techniques and practical situations in this specific place the following measures can be considered. 

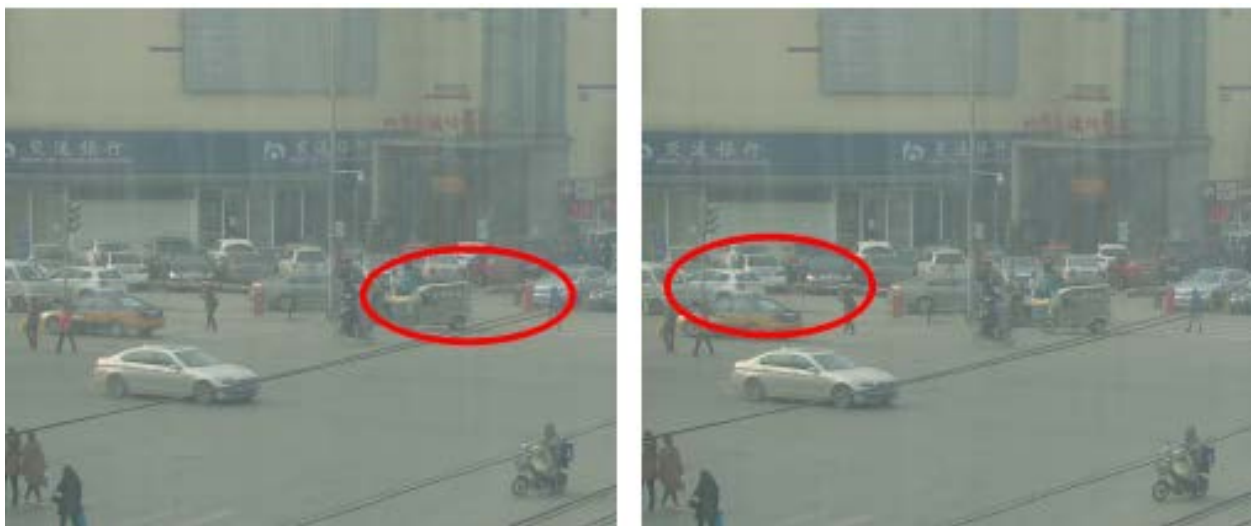

Figure 3. The location of access II \& III.
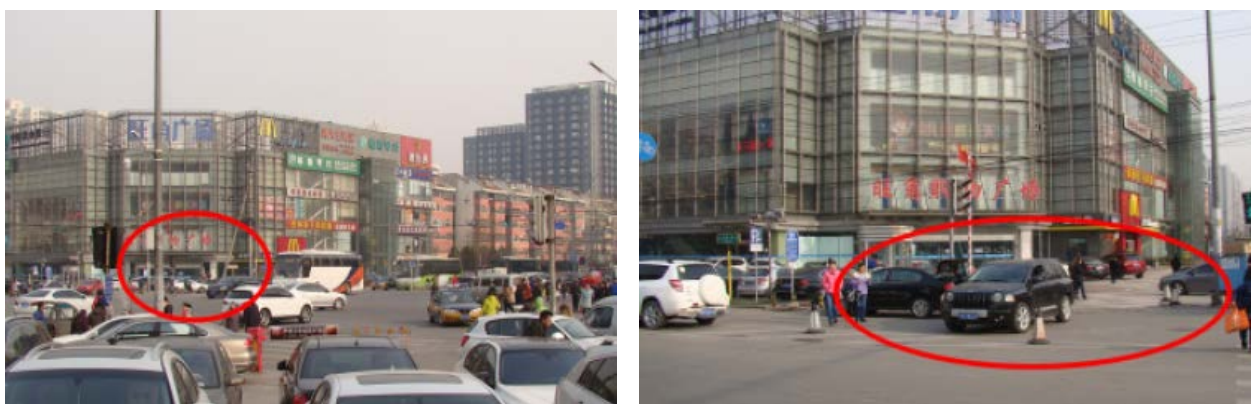

Figure 4. The location of access IV.

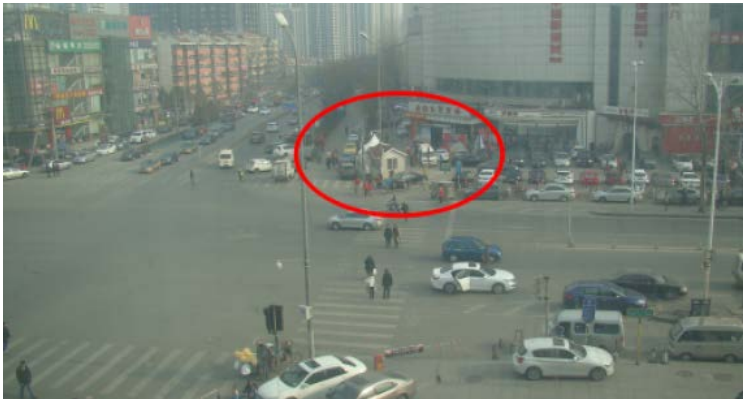

Figure 5. The situation of access V.

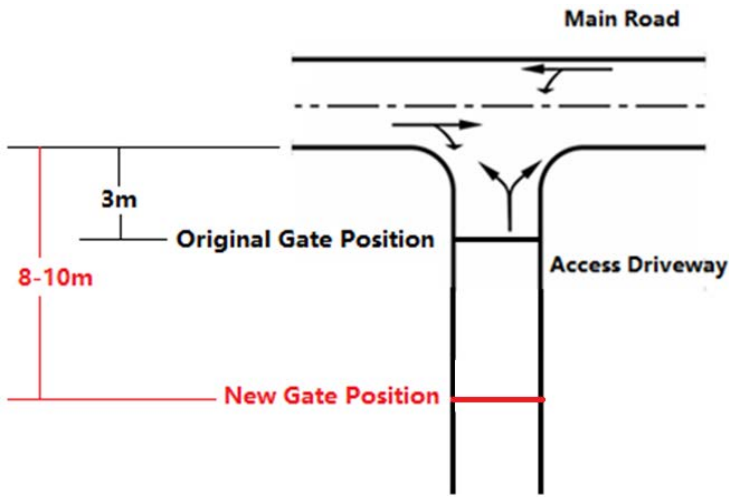

Figure 6. Move-back of the driveway gate. 


\subsection{Move Back the Gate}

For the access I, based on analysis of this access driveway, the flow will be more and more with the rush hour coming. At that time, the driveway will become congestion seriously. Therefore, in order to improve security, it would be an effective method to move back the gate of access (as shown in Figure 6) to allow right-in traffic to move smoothly without blocking the through traffic. In addition it is beneficial to provide a protected area for opposite traffic on the driveway to wait an opportunity to join in the flow.

\subsection{Remove the Access to the Main Road}

For the access III, the vehicle goes out through it. But, the exit is beside the inter-section, it is dangerous for the riders and pedestrian when the vehicle rushs out from the exit suddenly. Moreover, after the vehicle drive away exit, the direction of the vehicle is random, not a fixed direction. When the flow is much enough, it will really impact the traffic movements at intersection. So it is necessary to remove the exit (access III) to the main road. At the same time, the distance between the access and the intersection should be more than $100 \mathrm{~m}$.In this way, the vehicle can be more convenient into traffic flow and avoid collision or scratch events.

\subsection{Set the One-Way Traffic}

For the access IV \& V, it is necessary to set the one-way access because these accesses all open at the intersection. When the flow is much enough, it will really impact the traffic movements at intersection. For the access IV \& V, vehicles should be only come into the parking lot. In this way, the conflict point will be less 3 points than before.

\subsection{Ban of Illegal Parking on Curb-Lane}

For all the accesses, it is recommended to prohibit illegal curb parking at the en-trance/ exit of driveway to provide adequate visibility of drivers from driveway. In this way, it will enhance the safety for the turning movements.

\section{Conclusions}

In this study, a comprehensive survey of access driveway in commercial areas is conducted. Traffic characteristics at access driveways and safety problems are observed and discussed. A total of six driveways have been selected to conduct data analysis. In addition 4 necessary measures have been proposed for the specific case. However, it is still a first exploration of application of access management principles on residential areas in Beijing, China. Some recommendations for the future commercial areas development are proposed based on this study.

If driveway has to be placed at major road it is necessary to put physical median to disallow direct left turn movement from driveway, when the distance between driveway and the nearby signalized intersection is short.

Similarly, if access opens at the intersection, it is necessary to set the one-way traffic. 
In this way, it can relieve traffic pressure of the intersection and vehicles move more smoothly through each access.

For the access, especially the exit, it is not a good idea to set it beside the inter-section. It is wise to remove the access to the main road.

Whenever possible the gate at commercial area should be exclusively used either for vehicles or for pedestrians/bickers, not for both.

The curb parking should be always prohibited at any time.

\section{References}

[1] Committee on Access Management, Access Management Manual, Transportation Research Board, Washington DC, 2003.

[2] Preston, H., Newton, R. Albrecht, C. and Keltner, D. (1998) Statistical Relationship between Vehicular Crashes and Highway Access. Report MN/RC-1998-27. Local Road Research Board, Minnesota Department of Transportation, August 1998.

[3] Eisele, W.L., Frawley, W.E. and Toycen, C.M. (2004) Estimating the Impacts of Access Management Techniques: Final Results. Report 0-4221-2. Texas Transportation Institute, The Texas A\&M University System, College Station.

[4] Gluck, J.S., Haas, G., Mahmood, J. and Levinson, H.S. (2000) Driveway Spacing and Traffic Operations. TRB Circular E-C019: Urban Street Symposium. Transportation Research Board, Washington DC.

[5] Jerome, G., Jean, M., Michael, G. and Maya, V. (2005) Access Management: The Challenge of Retrofit Theory versus Reality, Transportation Research Board, Washington DC.

[6] Schultz, G.G., Braley, K.T. and Boschert, T. (2009) Prioritizing Access Management Implementation. Transportation Research Board, 8th National Conference on Access Management, Washington DC.

[7] Maze, T. and Plazak. D. (1997) Access Management Awareness Program: Phase II Report. Iowa Highway Research Board Project TR-402. Center for Transportation Research and Education, Iowa State University, Ames.

Submit or recommend next manuscript to SCIRP and we will provide best service for you:

Accepting pre-submission inquiries through Email, Facebook, LinkedIn, Twitter, etc. A wide selection of journals (inclusive of 9 subjects, more than 200 journals)

Providing 24-hour high-quality service

User-friendly online submission system

Fair and swift peer-review system

Efficient typesetting and proofreading procedure

Display of the result of downloads and visits, as well as the number of cited articles

Maximum dissemination of your research work

Submit your manuscript at: http://papersubmission.scirp.org/ 